\title{
Atmospheric trace metals measured at a regional background site (Welgegund) in South Africa
}

\author{
Andrew D. Venter ${ }^{1}$, Pieter G. van Zyl ${ }^{1}$, Johan P. Beukes ${ }^{1}$, Micky Josipovic ${ }^{1}$, Johan Hendriks ${ }^{1}$, Ville Vakkari ${ }^{2}$, and \\ Lauri Laakso ${ }^{1,2}$ \\ ${ }^{1}$ Unit of Environmental Sciences and Management, North-West University, Potchefstroom, South Africa \\ ${ }^{2}$ Finnish Meteorological Institute, Helsinki, Finland
}

Correspondence to: Pieter G. van Zyl (pieter.vanzyl@ nwu.ac.za)

Received: 22 September 2016 - Discussion started: 11 October 2016

Revised: 13 February 2017 - Accepted: 3 March 2017 - Published: 29 March 2017

\begin{abstract}
Atmospheric trace metals can cause a variety of health-related and environmental problems. Only a few studies on atmospheric trace metal concentrations have been conducted in South Africa. Therefore the aim of this study was to determine trace metal concentrations in aerosols collected at a regional background site, i.e. Welgegund, South Africa. $\mathrm{PM}_{1}, \mathrm{PM}_{1-2.5}$ and $\mathrm{PM}_{2.5-10}$ samples were collected for 13 months, and 31 atmospheric trace metal species were detected. Atmospheric iron $(\mathrm{Fe})$ had the highest concentrations in all three size fractions, while calcium (Ca) was the second-most-abundant species. Chromium $(\mathrm{Cr})$ and sodium (Na) concentrations were the third- and fourth-mostabundant species, respectively. The concentrations of the trace metal species in all three size ranges were similar, with the exception of $\mathrm{Fe}$, which had higher concentrations in the $\mathrm{PM}_{1}$ size fraction. With the exception of titanium (Ti), aluminium (Al) and manganese $(\mathrm{Mg}), 70 \%$ or more of the trace metal species detected were in the smaller size fractions, which indicated the influence of industrial activities. However, the large influence of wind-blown dust was reflected by $30 \%$ or more of trace metals being present in the $\mathrm{PM}_{2.5-10}$ size fraction. Comparison of trace metals determined at Welgegund to those in the western Bushveld Igneous Complex indicated that at both locations similar species were observed, with Fe being the most abundant. However, concentrations of these trace metal species were significantly higher in the western Bushveld Igneous Complex. Fe concentrations at the Vaal Triangle were similar to levels thereof at Welgegund, while concentrations of species associated with pyrometallurgical smelting were lower. Annual average Ni was 4 times higher, and annual average As was marginally higher
\end{abstract}

than their respective European standard values, which could be attributed to regional influence of pyrometallurgical industries in the western Bushveld Igneous Complex. All three size fractions indicated elevated trace metal concentrations coinciding with the end of the dry season, which could partially be attributed to decreased wet removal and increases in wind generation of particulates. Principal component factor analysis (PCFA) revealed four meaningful factors in the $\mathrm{PM}_{1}$ size fraction, i.e. crustal, pyrometallurgical-related and $\mathrm{Au}$ slimes dams. No meaningful factors were determined for the $\mathrm{PM}_{1-2.5}$ and $\mathrm{PM}_{2.5-10}$ size fractions, which was attributed to the large influence of wind-blown dust on atmospheric trace metals determined at Welgegund. Pollution roses confirmed the influence of wind-blown dust on trace metal concentrations measured at Welgegund, while the impact of industrial activities was also substantiated.

\section{Introduction}

Atmospheric aerosols either are directly emitted into the atmosphere (primary aerosols) from natural and/or anthropogenic sources or are formed through gaseous reactions and gas-to-particle conversions (secondary aerosols). Aerosols have high temporal and spatial variability, which increases the need for and importance of detailed physical and chemical characterisation on a regional scale in order to assess the impacts of aerosols (Pöschl, 2005). Particulate matter (PM) is classified according to its aerodynamic diameter, as $\mathrm{PM}_{10}$, $\mathrm{PM}_{2.5}, \mathrm{PM}_{1}$ and $\mathrm{PM}_{0.1}$, which relates to aerodynamic diameters being smaller than $10,2.5,1$ and $0.1 \mu \mathrm{m}$, respectively. 
Larger particulates have shorter lifetimes in the atmosphere than smaller particles, while the impacts of these species are also determined, to a large degree, by their size (Tiwari et al., 2012; Colbeck et al., 2011). The largest uncertainties in the estimation of direct and indirect radiative forcing from aerosols are related to the insufficient knowledge of the high spatial and temporal variability of aerosol concentrations, as well as their microphysical, chemical and radiative properties (IPCC, 2014). Aerosols consist of a large number of organic and inorganic compounds, of which typical inorganic species include ionic species and trace metals.

Natural sources of atmospheric trace metals include mineral dust, crustal species, oceans and biomass burning (wild fires), while major anthropogenic sources are pyrometallurgical processes, fossil fuel combustion and incineration (Pacyna and Pacyna, 2001). Larger aerosol particles $(>2.5 \mu \mathrm{m})$ are usually associated with natural emissions through processes such as rock weathering and soil erosion (Nriagu, 1989). Trace metal species usually associated with natural emissions include sodium $(\mathrm{Na})$, silicon $(\mathrm{Si})$, magnesium $(\mathrm{Mg})$, aluminium $(\mathrm{Al})$, potassium $(\mathrm{K})$, calcium $(\mathrm{Ca})$, titanium (Ti), chromium $(\mathrm{Cr})$, manganese $(\mathrm{Mn})$ and iron $(\mathrm{Fe})$ (Adgate et al., 2007). Arsenic (As), barium (Ba), cadmium (Cd), copper $(\mathrm{Cu})$, nickel $(\mathrm{Ni})$, zinc $(\mathrm{Zn})$, vanadium $(\mathrm{V})$, molybdenum (Mo), mercury $(\mathrm{Hg})$ and lead $(\mathrm{Pb})$ are mostly related to anthropogenic activities (Pacyna, 1998; Polidori et al., 2009). One of the most significant sources of anthropogenic trace metal emissions is the industrial smelting of metals. Industrial pyrometallurgical processes produce the largest emissions of As, $\mathrm{Cd}, \mathrm{Cu}, \mathrm{Ni}$ and $\mathrm{Zn}$ (Zahn et al., 2014). Cr, $\mathrm{Ba}, \mathrm{Mo}, \mathrm{Zn}, \mathrm{Pb}$ and $\mathrm{Cu}$ are typically associated with motorvehicle emissions and oil combustion, while $\mathrm{Fe}, \mathrm{Pb}$ and $\mathrm{Zn}$ are emitted from municipal waste incinerators (Adgate et al., 2007). However, most of these atmospheric trace metals are emitted through a combination of different anthropogenic sources (Polidori et al., 2009).

Although trace heavy metals, i.e. metals $>\mathrm{Ca}$, represent a relatively small fraction of atmospheric aerosols (with the exception of $\mathrm{Fe}$, which could contribute a few percent) (Colbeck, 2008), these species can cause a variety of health-related and environmental problems, depending on the aerosol composition, extent and time of exposure (Pöschl, 2005). The potential hazard of several toxic species is well documented as discussed, for instance, by Polidori et al. (2009), indicating that trace metals such as As, Cd, Co, $\mathrm{Cr}, \mathrm{Ni}, \mathrm{Pb}$ and $\mathrm{Se}$ are considered human and animal carcinogens even in trace amounts (CDC, 2015). It has also been shown that $\mathrm{Cu}, \mathrm{Cr}$ and $\mathrm{V}$ can generate reactive oxygenated species that can contribute to oxidative DNA damage (Nel, 2005). Furthermore, trace metals such as $\mathrm{Cr}$, Fe and $\mathrm{V}$ have several oxidation states that can participate in many atmospheric redox reactions (Seigneur and Constantinou, 1995), which can catalyse the generation of reactive oxygenated species (ROS) that have been associated with direct molecular damage and with the induction of biochemical synthe- sis pathways (Rubasinghege et al., 2010). Guidelines for atmospheric levels of many trace metals are provided by the World Health Organization (WHO) (WHO, 2005). In addition, lighter metals such as $\mathrm{Si}, \mathrm{Al}$ and $\mathrm{K}$ are the most abundant crustal elements (next to oxygen), which can typically constitute up to $50 \%$ of remote continental aerosols. These species are usually associated with the impacts of aerosols on respiratory diseases and climate.

South Africa has the largest industrialised economy in Africa, with significant mining and metallurgical activities. South Africa is a well-known source region of atmospheric pollutants, which is signified by three regions being classified through legislation as air pollution priority areas, i.e. Vaal Triangle Airshed Priority Area (DEAT, 2006), Highveld Priority Area (DEAT, 2007) and Waterberg-Bojanala Priority Area (DEA, 2012). Air quality outside these priority areas is often adversely affected due to regional transport and the general climatic conditions, such as low precipitation and poor atmospheric mixing in winter. Only a few studies on the concentrations of atmospheric trace metals in South Africa have been conducted (Van Zyl et al., 2014; Kgabi, 2006; Kleynhans, 2008). In addition, most of these studies were also conducted within these priority areas containing a significant number of large point sources, and regional impacts of atmospheric trace metals could therefore not be assessed.

In this study, trace metals were determined in three size ranges in aerosol samples collected for 1 year at the Welgegund atmospheric measurement station in South Africa. Welgegund is a comprehensively equipped regional background atmospheric measurement station that is $\sim 100 \mathrm{~km}$ downwind of the most important source regions in the interior of South Africa (e.g. Tiitta et al., 2014). These source regions include the western Bushveld Igneous Complex (situated within the Waterberg-Bojanala Priority Area), where a large number of pyrometallurgical smelters are situated, which can be considered of global importance, e.g. as a supplier of platinum group metals (PGMs) utilised in automotive catalytic converters and as the dominant global chromiumsupplying region. In an effort to determine major sources of trace metals on a regional scale, source apportionment was also performed by applying principal component factor analysis (PCFA).

\section{Experimental}

\subsection{Site description}

Aerosol sampling was performed at Welgegund (http: //www.welgegund.org; $26^{\circ} 34^{\prime} 11.23^{\prime \prime} \mathrm{S}, \quad 26^{\circ} 56^{\prime} 21.44^{\prime \prime} \mathrm{E}$; $1480 \mathrm{~m}$ a.s.l., above sea level) in South Africa, which is a regional background station with no large point sources in close proximity. As indicated in Fig. 1 and the $96 \mathrm{~h}$ overlay back trajectories presented in Fig. S1 in the Supplement, Welgegund is situated in the interior of South Africa and 
is frequently affected by air masses moving over the most important anthropogenic/industrial source regions in the interior (Beukes et al., 2013; Tiitta et al., 2014; Jaars et al., 2014; Vakkari et al., 2015; Booyens et al., 2015). Also indicated in Fig. 1 are the major industrial point sources, i.e. coal-fired power plants, petrochemical industries and pyrometallurgical smelters. In Beukes et al. (2013), Tiitta, et al. (2014) and Jaars et al. (2014), reasons for the site selection, prevailing biomes and pollution sectors are discussed in detail. In summary, air masses affecting the site from the west, between north- and south-west, are considered to be representative of the regional background, since they move over a sparsely populated region without any large point sources. In the sector between north and north-east from Welgegund lies the western limb of the Bushveld Igneous Complex, which holds 11 pyrometallurgical smelters (most commonly related to the production of $\mathrm{Cr}, \mathrm{Fe}, \mathrm{V}$ and $\mathrm{Ni}$ ) within a $\sim 55 \mathrm{~km}$ radius, in addition to other industrial, mining and residential sources. In the north-east to eastern sector, the Johannesburg-Pretoria (Jhb-Pta) conurbation is situated, which is inhabited by more than 10 million people, making it one of the 40 largest metropolitan areas in the world. In the sector between east and south-east from Welgegund is the Vaal Triangle region, where most of the South African petrochemical and petrochemically related industries are located, together with other large point sources, such as two coal-fired power stations (without desulfurisation, de- $\mathrm{SO}_{x}$, and denitrification, de- $\mathrm{NO}_{x}$ ) and large pyrometallurgical smelters. Welgegund is also affected by the Mpumalanga Highveld in the eastern sector (indicated by MP in Fig. 1). In this region, there are 11 coal-fired power stations (without de-SO $\mathrm{S}_{x}$ and de- $\mathrm{NO}_{x}$ technologies) with a combined installed generation capacity of ca. $46 \mathrm{GW}$, as well as a very large petrochemical plant, several pyrometallurgical smelters and numerous coal mines, all within a ca. $60 \mathrm{~km}$ radius. Furthermore, Welgegund is also affected by air masses passing over the pyrometallurgical smelters in the eastern limb of the Bushveld Igneous Complex situated north-east from Welgegund in the Limpopo province (indicated by LP in Fig. 1).

\subsection{Sampling and analysis}

Aerosol samples were collected for 1 year from 24 November 2010 until 28 December 2011. A Dekati (Dekati Ltd., Finland) $\mathrm{PM}_{10}$ cascade impactor (ISO23210) equipped with PTFE filters was used to collect different particulate size ranges, i.e. $\mathrm{PM}_{2.5-10}$ (aerodynamic diameter ranging between 2.5 and $10 \mu \mathrm{m}$ ), $\mathrm{PM}_{1-2.5}$ (aerodynamic diameter ranging between 1 and $2.5 \mu \mathrm{m}$ ) and $\mathrm{PM}_{1}$ (aerodynamic diameter $<1 \mu \mathrm{m}$ ). The pump flow rate was set at $30 \mathrm{~L} \mathrm{~min}^{-1}$. Samples were collected continuously for 1 week, after which filters were changed. A total of 54 samples were collected for the 54-week sampling period for each of the three size ranges. The trace metals in the PM collected on the 216 PTFE filters

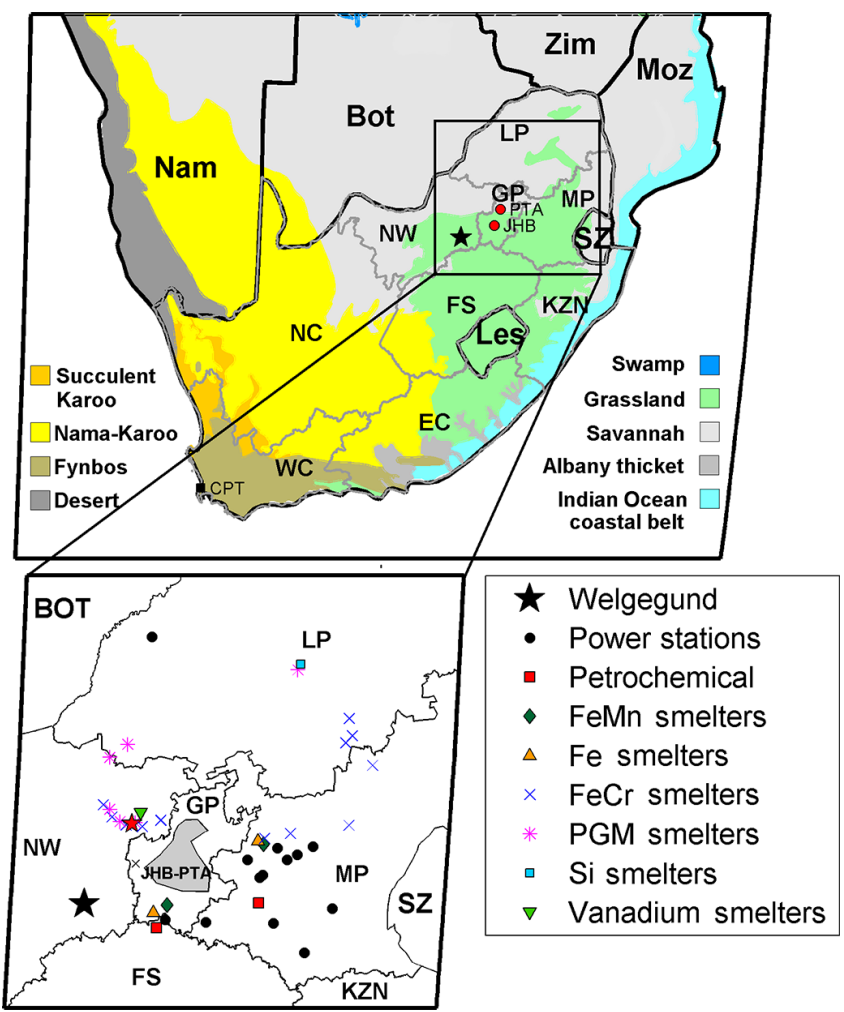

Figure 1. A bio-geographical map indicating Welgegund (black star), as well as the major point sources and the JohannesburgPretoria (JHB-PTA) conurbation. Neighbouring countries to South Africa (Nam: Namibia; Bot: Botswana; Zim: Zimbabwe; Mos: Mozambique; SZ: Swaziland; Les: Lesotho) as well as South African provinces (LP: Limpopo; NW: North West; FS: Free State; KZN: Kwa-Zulu Natal; MP: Mpumalanga; NC: Northern Cape; EC: Eastern Cape; WC: Western Cape) are also indicated.

were extracted by hot acid leaching $\left(20 \mathrm{~mL} \mathrm{HNO}_{3}\right.$ and $5 \mathrm{~mL}$ $\mathrm{HCl})$ and diluted in deionised water $(18.2 \mathrm{M} \Omega$ ) up to $100 \mathrm{~mL}$ for subsequent analysis with an inductively coupled plasma mass spectrometer (ICP-MS). In total, 31 trace metals could be detected with ICP-MS analysis, which included $\mathrm{Na}, \mathrm{Mg}$, $\mathrm{Al}, \mathrm{K}, \mathrm{Ca}, \mathrm{Ti}, \mathrm{Cr}, \mathrm{Mg}, \mathrm{Fe}, \mathrm{As}, \mathrm{Ba}, \mathrm{Cd}, \mathrm{Cu}, \mathrm{Ni}, \mathrm{Zn}, \mathrm{V}, \mathrm{Mo}$, $\mathrm{Hg}, \mathrm{Pb}$, manganese $(\mathrm{Mn})$, cobalt $(\mathrm{Co})$, platinum $(\mathrm{Pt})$, beryllium (Be), boron (B), selenium (Se), palladium ( $\mathrm{Pd})$, barium $(\mathrm{Ba})$, gold $(\mathrm{Au})$, thallium $(\mathrm{Tl})$, antimony $(\mathrm{Sb})$ and uranium (U). Trace metal concentrations below the detection limit of the ICP-MS were considered to have concentrations half the detection limit of the species considered. This is a precautionary assumption that is frequently used in health-related environmental studies (e.g. Van Zyl et al., 2014).

\subsection{Statistical analysis}

In an attempt to identify possible sources of trace metals detected, PCFA with a varimax rotation (v. 13.0 SPSS Inc., Chicago, IL, USA) was performed on the dataset. PCFA has been used widely in receptor modelling to identify major 
source sectors. The technique operates on sample-to-sample fluctuations of the normalised concentrations. It does not directly yield concentrations of species from various sources but identifies a minimum number of common factors for which the variance often accounts for most of the variance of species (e.g. Van Zyl et al., 2014, and references therein). The trace metal concentrations determined for the 32 species in all three size fractions were subjected to multivariate analysis of Box-Cox transformation and varimax rotation, followed by subsequent PCFA. In addition, Spearman correlations were also performed in order to establish correlations between trace metals in order to substantiate results obtained with PCFA.

\section{Results}

\subsection{Size-resolved concentrations and size distribution of trace metals}

Although nitric digestion is commonly used to extract and dissolve metals for ICP-MS analysis, it is unable to dissolve and extract silicate minerals. Therefore $\mathrm{Si}$ could not be quantified in this study. In addition, this limitation of the nitric digestion could also result in determining lower concentrations of metals associated with the silicate component such as $\mathrm{Al}, \mathrm{K}, \mathrm{Mg}, \mathrm{Ca}$ and $\mathrm{Fe}$, especially for samples that have high aeolian dust content. It is estimated that approximately only $7 \% \mathrm{Si}$ and $30 \% \mathrm{Al}$ is extracted by nitric acid leaching (Ahn et al., 2011). Therefore, since $\mathrm{Si}$ and $\mathrm{Al}$ are considered to be the most abundant crustal elements after oxygen, the trace metal concentrations presented in this paper should be related to the limitation of nitric digestion, i.e. Si-Al-K components missing from the digestions phase. Silicate minerals can be dissolved in a mixture of aqua regia and hydrofluoric acid. However, this is a very difficult procedure, which results in the formation of gaseous $\mathrm{SiF}_{3}$ that is not determinable by ICP-MS.

In Fig. 2, the combined trace metal concentrations in all three size fractions (Fig. 2a), as well as concentrations of the trace metals determined in each of the size fractions, are presented (Fig. 2b, c and d). $\mathrm{Hg}$ and Ag concentrations were below the detection limit of the analytical technique for the entire sampling period in all three size fractions, and the concentrations of these species are therefore excluded from Fig. 2.

The highest median concentration was determined for atmospheric $\mathrm{Fe}$, i.e. $1.4 \mu \mathrm{g} \mathrm{m}^{-3}$, while $\mathrm{Ca}$ was the secondmost-abundant species, with a median concentration of $1.1 \mu \mathrm{g} \mathrm{m}^{-3}$. Fe concentrations were significantly higher than the other trace metal species determined at Welgegund. $\mathrm{Cr}$ and $\mathrm{Na}$ concentrations were the third- and fourth-mostabundant species, respectively. The median $\mathrm{Cr}$ concentration was $0.54 \mu \mathrm{g} \mathrm{m}^{-3}$, while the median $\mathrm{Na}$ level was $0.39 \mu \mathrm{g} \mathrm{m}^{-3}$. Relatively higher concentrations were also de- termined for $\mathrm{Al}, \mathrm{B}, \mathrm{Mg}, \mathrm{Ni}$ and $\mathrm{K}$, with median concentrations of $0.20,0.30,0.18,0.02$ and $0.18 \mu \mathrm{g} \mathrm{m}^{-3}$, respectively. The combined atmospheric concentrations of the other trace metals in all the size fractions were clearly lower.

A comparison of the trace metal concentrations in the three size fractions indicates that $\mathrm{Fe}$ and $\mathrm{Ca}$ were the most abundant species in all three size fractions. Fe had the highest median concentration in the $\mathrm{PM}_{1}$ size fraction, i.e. $0.63 \mathrm{\mu g} \mathrm{m}^{-3}$, while $\mathrm{Ca}$ had the highest median concentrations in the $\mathrm{PM}_{1-2.5}$ and $\mathrm{PM}_{2.5-10}$ size fractions, i.e. 0.39 and $0.29 \mathrm{\mu g} \mathrm{m}^{-3}$, respectively. The median concentration of $\mathrm{Fe}$ in the $\mathrm{PM}_{1}$ was significantly higher than the median concentrations thereof in the $\mathrm{PM}_{1-2.5}$ and $\mathrm{PM}_{2.5-10}$ size fractions. The third- and fourth-most-abundant species in all three size fractions were $\mathrm{Cr}$ and $\mathrm{Na}$, respectively. Relatively higher concentrations were also determined for $\mathrm{Al}, \mathrm{B}, \mathrm{Mg}, \mathrm{Ni}$ and $\mathrm{K}$ in all three size fractions. With the exception of Fe concentrations in the $\mathrm{PM}_{1}$ size fraction, the concentrations of each of the trace metal species were similar in all size fractions.

In Fig. 3, the mean size distributions of each of the trace metal species identified above the detection limit in the three size fractions are presented. Ti had a significantly higher contribution (80\%) in the $\mathrm{PM}_{2.5-10}$ size fraction, while $\mathrm{Al}$ and $\mathrm{Mg}$ also had relatively higher contributions ( $\sim 50$ and $45 \%$, respectively) in the $\mathrm{PM}_{2.5-10}$ size fraction. The $\mathrm{PM}_{2.5-10}$ size fraction is usually associated with wind-blown dust. Seventy percent or more of all the other trace metal species detected were in the two smaller size fractions, with approximately 35 to $60 \%$ occurring in the $\mathrm{PM}_{1}$ size fraction. The presence of these trace metal species predominantly in the smaller size fractions, especially considering the relatively large contribution in the $\mathrm{PM}_{1}$ size fractions, indicates the influence of industrial (high-temperature) activities on air masses measured at Welgegund. Trace metal concentrations measured at Marikana, situated within the western Bushveld Igneous Complex, indicated that $\mathrm{Cr}, \mathrm{Mn}, \mathrm{V}, \mathrm{Zn}$ and Ni occurred almost exclusively in the $\mathrm{PM}_{2.5}$ size fraction, with no contribution by coarser particles (Van Zyl et al., 2014). The large influence of wind-blown dust on trace metal concentrations determined at Welgegund is also reflected, with approximately $30 \%$ of most of these trace metals being present in the $\mathrm{PM}_{2.5-10}$ size fraction.

From Figs. 2 and 3 it is evident that a major source of trace metal species in all three size fractions can be considered to be wind-blown dust typically comprising $\mathrm{Fe}, \mathrm{Ca}, \mathrm{Mg}, \mathrm{Al}, \mathrm{K}$ and Ti (Polidori et al., 2009). As mentioned, Welgegund is a regional background location affected by air masses passing over large pollutant source regions and a relatively clean background area (Fig. 1). In Fig. S1 $96 \mathrm{~h}$ overlay back trajectories arriving hourly at Welgegund for the entire sampling period (24 November 2010 until 28 December 2011) are presented. From Figs. 1 and S1 it is evident that Welgegund is frequently impacted by long-range transport of air masses passing over the relatively clean background region in the west (between north- and south-west). It is ev- 

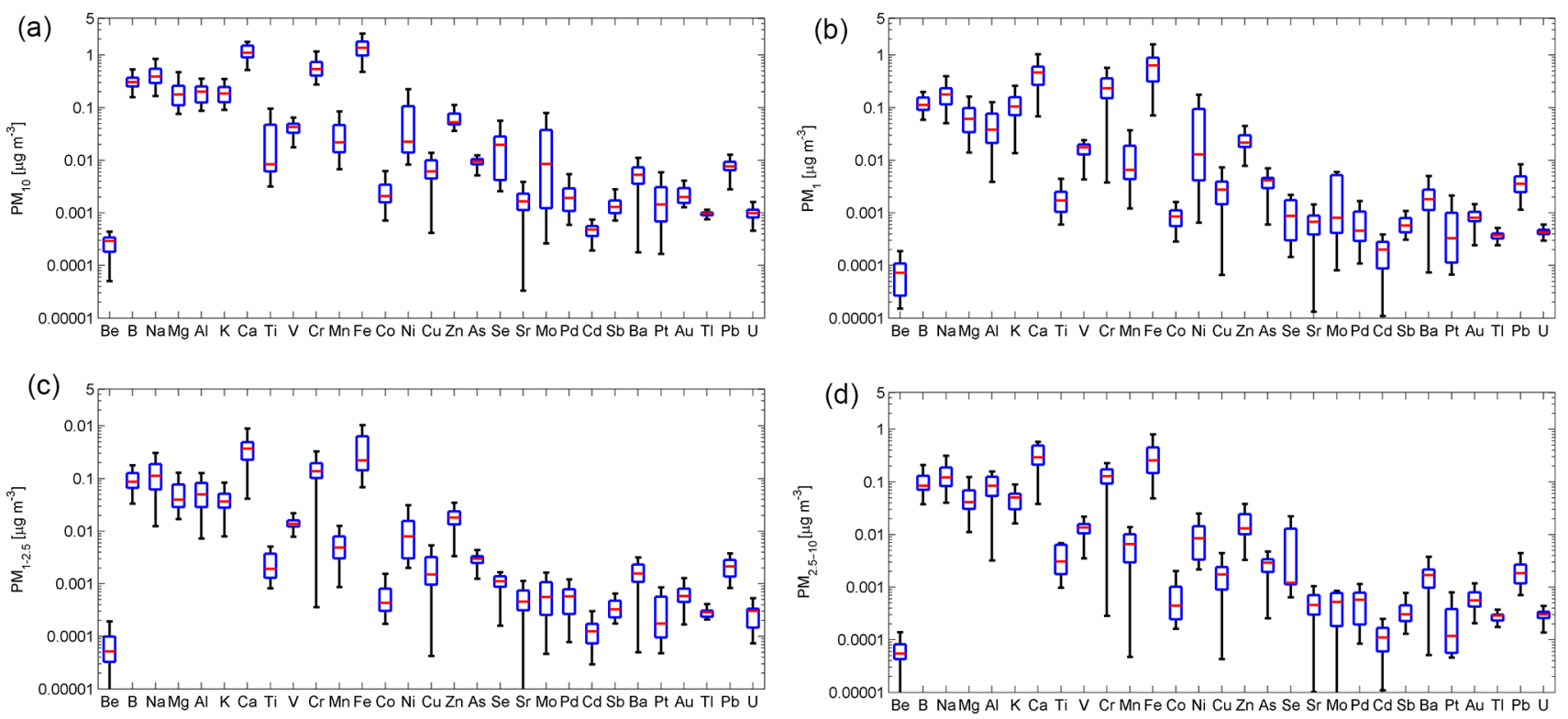

Figure 2. Box-and-whisker plots of trace metal concentrations in the (a) $\mathrm{PM}_{10}$ (sum of trace metal concentrations in the three size fractions), (b) $\mathrm{PM}_{1}$, (c) $\mathrm{PM}_{1-2.5}$ and (d) $\mathrm{PM}_{2.5-10}$ size fractions. The red line indicates the median concentrations, the blue rectangle of the box plot represents the 25 th and 75 th percentiles, and the whiskers indicate \pm 2.7 times the standard deviation.

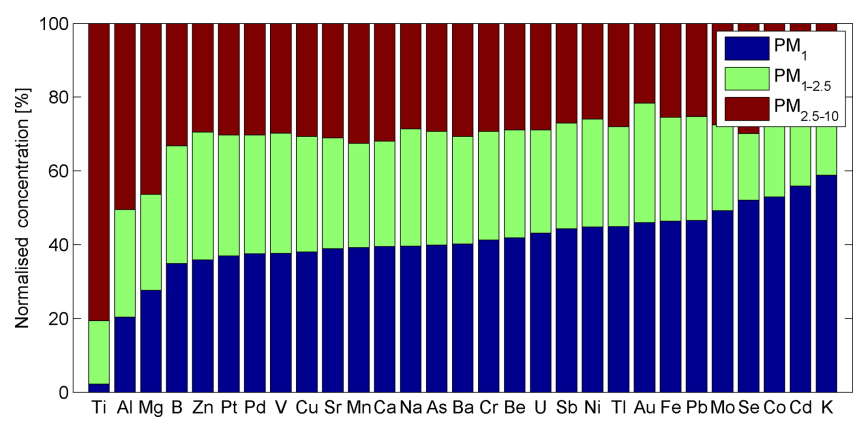

Figure 3. Mean size distributions of individual trace metal species detected. Species are arranged by increasing concentration in the $\mathrm{PM}_{1}$ size fraction.

ident from Fig. 1 that the arid Nama-Karoo biome is situated within this region west of Welgegund, which could be a potential regional source for wind-blown dust. In addition, Jaars et al. (2016) also indicated the extent of agricultural activities within a $60 \mathrm{~km}$ radius from Welgegund, which could be a significant local source of wind-blown dust. In addition, Fig. S1 indicate that Welgegund is also frequently affected by air masses moving over the western Bushveld Igneous Complex, which is associated with a large number of pyrometallurgical smelters (e.g. ferrochrome, platinum and base metals) and mining activities (Venter et al., 2012; Tiitta et al., 2014; Jaars et al., 2014). This source region could therefore contribute to regional elevated levels of $\mathrm{Fe}, \mathrm{Cr}, \mathrm{Ni}, \mathrm{Zn}, \mathrm{Mn}$ and $\mathrm{V}$ measured at Welgegund. Venter at al. (2016) indicated that $\mathrm{Cr}(\mathrm{VI})$ concentrations were elevated in air masses that had passed over the western Bushveld Igneous Complex with the majority of $\mathrm{Cr}(\mathrm{VI})$ in the smaller $\mathrm{PM}_{2.5}$ size fraction. The possible sources of trace metal species measured at Welgegund will be further explored in Sect. 3.5.

\subsection{Contextualisation of atmospheric trace metal concentrations}

In Table 1, the annual average $\mathrm{PM}_{10}$ trace metal concentrations determined in this study are compared to trace metal concentrations determined in other studies. Although the aerosol sampling periods and frequencies for most of these previous trace metal studies were not similar to the aerosol sampling period and frequency in this investigation, these results could be utilised to contextualise the trace metal concentrations. As mentioned previously, $\mathrm{Hg}$ and $\mathrm{Ag}$ concentrations were below the detection limit of the analytical technique for the entire sampling period in all three size fractions. Therefore, concentrations presented for these species are most likely to be an overestimate due to the precautionary assumption.

The annual mean $\mathrm{PM}_{10}$ trace metal concentrations at Welgegund (Table 1) were typically lower than previous studies conducted in South Africa (Kgabi, 2006; Kleynhans, 2008; Van Zyl et al., 2014). This is expected, as Welgegund is a regional background location and the previous studies were conducted at sites within two priority areas, as mentioned previously. These sites were also located in two of the major source regions influencing air masses arriving at Welgegund. Marikana (Van Zyl et al., 2014) and Rustenburg (Kgabi, 2006) are situated approximately $100 \mathrm{~km}$ north-north-west 
Table 1. Annual mean $\mathrm{PM}_{10}$ trace metal concentrations measured at Welgegund; annual average standards; and annual average trace metal levels determined in other studies in South Africa, China and Europe. Concentration values are presented in $\mu \mathrm{g} \mathrm{m}{ }^{-3}$. Italic typeface indicates concentrations of species that were below the detection limit of the analytical technique for the entire sampling period in all three size fractions.

\begin{tabular}{|c|c|c|c|c|c|c|c|c|c|}
\hline \multirow[b]{2}{*}{$\begin{array}{l}\mathrm{PM}_{10} \\
\text { annual } \\
\text { average }\end{array}$} & \multirow[b]{2}{*}{$\begin{array}{r}\text { ICP detection } \\
\text { limits } \\
\left(\times 10^{-5}\right)\end{array}$} & \multirow[b]{2}{*}{$\begin{array}{r}\text { Welgegund } \\
\text { (this } \\
\text { study) }\end{array}$} & \multirow[b]{2}{*}{$\begin{array}{r}\text { Annual } \\
\text { standard }\end{array}$} & \multicolumn{3}{|c|}{ South Africa } & \multirow[b]{2}{*}{$\begin{array}{r}\text { Beijing, China } \\
\text { (Duan et al., } \\
\text { 2012) }\end{array}$} & \multirow[b]{2}{*}{$\begin{array}{r}\text { West coast of } \\
\text { Portugal (Pio } \\
\text { et al., 1996) }\end{array}$} & \multirow[b]{2}{*}{$\begin{array}{r}\text { Spain } \\
\text { (Querol et } \\
\text { al., 2007) }\end{array}$} \\
\hline & & & & $\begin{array}{r}\text { Marikana } \\
\text { (Van Zyl } \\
\text { et al., 2014) }\end{array}$ & $\begin{array}{r}\text { Rustenburg } \\
\text { (Kgabi, } \\
2006)\end{array}$ & $\begin{array}{r}\text { Vaal Triangle } \\
\text { (Kleynhans, } \\
2008)\end{array}$ & & & \\
\hline $\mathrm{Be}$ & 0.293 & 0.0002 & & 0.020 & & & 0.100 & & $<0.001$ \\
\hline B & 4.415 & 0.28 & & 1.300 & & & & & \\
\hline $\mathrm{Na}$ & 8.515 & 0.38 & & 1.410 & & 2.800 & 1.450 & & \\
\hline $\mathrm{Mg}$ & 3.504 & 0.23 & & 2.040 & & 1.000 & 0.637 & & \\
\hline $\mathrm{Al}$ & 6.960 & 0.17 & & 1.280 & & & 2.180 & 0.200 & \\
\hline $\mathrm{K}$ & 12.98 & 0.14 & & 0.680 & & 1.300 & 1.170 & & \\
\hline $\mathrm{Ca}$ & 19.88 & 1.1 & & 1.080 & & & 0.996 & & \\
\hline $\mathrm{Ti}$ & 5.729 & 0.072 & & 0.120 & 0.180 & 0.020 & 0.069 & & 0.019 \\
\hline V & 1.736 & 0.037 & $1.000^{\mathrm{b}, \mathrm{d}}$ & 0.040 & 0.160 & & & $<0.001$ & 0.005 \\
\hline $\mathrm{Cr}$ & 0.233 & 0.50 & $2.5 \times 10^{-5 \mathrm{a}, \mathrm{c}}$ & 0.240 & 1.370 & 0.050 & 0.022 & $<0.001$ & 0.001 \\
\hline $\mathrm{Mn}$ & 2.064 & 0.026 & $0.15^{\mathrm{c}}$ & 0.060 & 4.390 & 0.120 & 0.036 & 0.002 & 0.005 \\
\hline $\mathrm{Fe}$ & 15.86 & 1.2 & & 2.540 & 9.760 & 1.280 & 1.090 & 0.028 & \\
\hline Co & 0.8146 & 0.0035 & & 0.140 & & & $<0.001$ & & $<0.001$ \\
\hline $\mathrm{Ni}$ & 4.000 & 0.079 & $0.020^{\mathrm{d}}$ & 0.330 & 0.770 & 0.040 & 0.020 & $<0.001$ & 0.003 \\
\hline $\mathrm{Cu}$ & 3.529 & 0.0069 & & 0.180 & 0.210 & 0.050 & 0.010 & 0.003 & 0.008 \\
\hline $\mathrm{Zn}$ & 14.13 & 0.053 & & 0.490 & 0.340 & 0.090 & 0.027 & 0.003 & 0.026 \\
\hline As & 4.730 & 0.0084 & $0.006^{\mathrm{d}}$ & 0.260 & & & 0.003 & 0.002 & $<0.001$ \\
\hline $\mathrm{Se}$ & 10.51 & 0.0074 & & 0.580 & & & 0.001 & $<0.001$ & $0.001<$ \\
\hline $\mathrm{Sr}$ & 0.819 & 0.0017 & & & & & 0.010 & & 0.005 \\
\hline Mo & 0.421 & 0.015 & & & & & 0.007 & & 0.004 \\
\hline $\mathrm{Pd}$ & 7.394 & 0.0018 & & 0.410 & & & & & \\
\hline $\mathrm{Ag}$ & 1.030 & 0.0005 & & & & & $<0.001$ & & \\
\hline $\mathrm{Cd}$ & 0.637 & 0.0004 & $0.005^{\mathrm{c}, \mathrm{d}}$ & 0.030 & & & $<0.001$ & $<0.001$ & $<0.001$ \\
\hline $\mathrm{Sb}$ & 0.444 & 0.0013 & & & & & $<0.001$ & & $<0.001$ \\
\hline $\mathrm{Ba}$ & 3.194 & 0.0040 & & 0.140 & & & 0.018 & & $<0.008$ \\
\hline $\mathrm{Pt}$ & 6.962 & 0.0016 & & 0.350 & & & & & \\
\hline $\mathrm{Au}$ & 7.340 & 0.0031 & & 0.380 & & & & & \\
\hline $\mathrm{Hg}$ & 9.971 & 0.0002 & $1.000^{\mathrm{c}}$ & 0.550 & & & & & \\
\hline $\mathrm{Tl}$ & 4.917 & 0.0007 & & 0.270 & & & & & $<0.001$ \\
\hline $\mathrm{Pb}$ & 2.592 & 0.0078 & $0.5^{\mathrm{c}, \mathrm{d}, \mathrm{e}}$ & 0.080 & 0.420 & 0.040 & 0.053 & 0.003 & 0.009 \\
\hline $\mathrm{U}$ & 8.527 & 0.0009 & & & & & & & \\
\hline
\end{tabular}

from Welgegund within the western Bushveld Igneous Complex source region, while the site in the Vaal Triangle (Kleynhans, 2008) source region is situated approximately $90 \mathrm{~km}$ east from Welgegund.

Fe was also the most abundant species at Marikana and Rustenburg, with significantly higher concentrations than at Welgegund. $\mathrm{Mg}$ was the second-most-abundant species at Marikana, while $\mathrm{Mn}$ and $\mathrm{Cr}$ concentrations were the second and third highest, respectively, at Rustenburg. Cr levels at Rustenburg were approximately 2.5 times higher than levels thereof at Welgegund. However, $\mathrm{Cr}$ concentrations measured at Welgegund were approximately 2 times higher than $\mathrm{Cr}$ levels determined at Marikana, which could be attributed to the long-range transport of $\mathrm{Cr}$ units (Figs. 1 and $\mathrm{S} 1$ ). Venter et al. (2016) also indicated that other combustion sources outside the western Bushveld Igneous Complex contributed to the atmospheric $\mathrm{Cr}(\mathrm{VI})$ concentrations at Welgegund. Ni and
Zn concentrations at Welgegund were an order of magnitude lower than levels thereof at Marikana and Rustenburg, while $\mathrm{Mn}$ and $\mathrm{V}$ concentrations were significantly lower than levels thereof measured at Rustenburg. Similar to Welgegund, Na, $\mathrm{B}$ and $\mathrm{Al}$ were also relatively abundant at Marikana, with concentrations of these species an order of magnitude higher at Marikana. Fe concentrations were similar at Vaal Triangle than levels thereof at Welgegund, while the annual average $\mathrm{Na}$ concentration was 7 times higher and the annual average $\mathrm{K}$ level was an order of magnitude higher at the Vaal Triangle. $\mathrm{Cr}, \mathrm{Ni}$ and $\mathrm{Zn}$, typically associated with pyrometallurgical industries, were significantly lower in the Vaal Triangle than levels thereof at Welgegund. However, Mn concentrations at the Vaal Triangle were higher than levels thereof at Welgegund and Marikana. This can be attributed to the presence of a ferromanganese (FeMn) smelter in the Vaal Triangle region, as indicated in Fig. 1. 
The atmospheric trace metal concentrations determined at Welgegund were also compared to measurements at regional background sites near Beijing, China (Duan et al., 2012); the west coast of Portugal (Pio et al., 1996); and Spain (Querol et al., 2007). Al concentrations near Beijing were significantly higher than concentrations of other trace metal species, while $\mathrm{Na}$ was the second-most-abundant species. Elevated levels of $\mathrm{K}, \mathrm{Fe}$ and $\mathrm{Ca}$ were also determined near Beijing. Al, $\mathrm{Na}$ and $\mathrm{K}$ concentrations were an order of magnitude higher than levels of these species determined at Welgegund, while Fe levels were twice as low near Beijing. All the other trace metal species measured near Beijing (with the exception of $\mathrm{Ca}, \mathrm{Pb}$ and $\mathrm{Mn}$ ) were an order or 2 orders of magnitude lower than concentrations of these species at Welgegund. Annual average trace metal concentrations determined at the two European regional background sites were an order or 2 orders of magnitude lower than trace metal levels determined at Welgegund. The generally lower trace metal concentration determined at these sites in China and Europe than at Welgegund can be attributed to the sites in China and Europe being more removed from a conglomeration of metal sources.

Also indicated in Table 1 are the existing ambient air quality guidelines and standard values for trace metal species prescribed by the WHO Air Quality Guidelines for Europe (WHO, 2005), the European Commission Air Quality Standards (ECAQ, 2008) and the South African National Air Quality Standards of the South African Department of Environmental Affairs (DEA) (DEA, 2009). There are currently only guidelines and standards for seven trace metal species, of which each of the above-mentioned institutions only prescribe limit values for some. Comparison of the annual average trace metal concentrations determined at Welgegund with the annual average standard values indicates that $\mathrm{Ni}$ and As exceeded standards set by the European Commission of Air Quality Standards. The annual average Ni concentration of $0.079 \mathrm{~g} \mathrm{~m} \mathrm{~m}^{-3}$ was approximately 4 times higher than the European standard value of $0.02 \mu \mathrm{g} \mathrm{m}^{-3}$, while the annual average As level of $0.0084 \mu \mathrm{g} \mathrm{m}^{-3}$ marginally exceeded the annual standard of $0.006 \mu \mathrm{g} \mathrm{m}^{-3}$. These exceedances can most probably be ascribed to the regional impacts of pyrometallurgical activities in the Bushveld Igneous Complex. Van Zyl et al. (2014) indicated that the exceedance of $\mathrm{Ni}$ at Marikana situated within the western Bushveld Igneous Complex could be attributed to base metal refining.

The WHO guideline of $2.5 \times 10^{-5} \mu \mathrm{g} \mathrm{m}^{-3}$ listed for $\mathrm{Cr}$ is only for atmospheric concentrations of $\mathrm{Cr}(\mathrm{VI})$ with a lifetime risk of $1: 1000000$. The $0.50 \mu \mathrm{g} \mathrm{m}^{-3}$ annual average $\mathrm{Cr}$ concentration determined can therefore not be compared to the guideline, since this value represents the total atmospheric $\mathrm{Cr}$ concentrations in all the oxidation states. $\mathrm{V}$ only has a $24 \mathrm{~h}$ standard value. Therefore, $\mathrm{V}$ concentrations determined in this study cannot directly be compared to this standard. However, the $24 \mathrm{~h}$ average calculated from the highest weekly $\mathrm{V}$ concentration $\left(0.084 \mu \mathrm{g} \mathrm{m}^{-3}\right)$ was $0.012 \mu \mathrm{g} \mathrm{m}^{-3}$, which was
2 orders of magnitude lower than the $24 \mathrm{~h} \mathrm{~V}$ standard of the European Commission Air Quality Standards.

Since $\mathrm{Pb}$ is the only trace metal for which a South African ambient air quality standard exists, it must also be noted that $\mathrm{Pb}$ concentrations did not exceed any standard. The annual average $\mathrm{Pb}$ concentrations determined at Welgegund $\left(0.0078 \mu \mathrm{g} \mathrm{m}^{-3}\right)$ were an order of magnitude lower than levels thereof at Marikana and Vaal Triangle, and three orders of magnitude lower than $\mathrm{Pb}$ levels determined at Rustenburg. However, the annual average $\mathrm{Pb}$ concentrations at Vaal Triangle, Marikana and Rustenburg were below the standard value (Kleynhans, 2008; Van Zyl et al., 2014; Kgabi, 2006). These low $\mathrm{Pb}$ concentrations can be partially ascribed to de-leading of petrol in South Africa. Furthermore, $\mathrm{Pb}$ concentrations determined at Beijing were similar to levels thereof determined at Welgegund.

Since the measurement of the ambient $\mathrm{Hg}$ concentrations is receiving increasing attention in South Africa and it is foreseen that a standard value for $\mathrm{Hg}$ levels will be prescribed in the near future, it is also important to refer to the $\mathrm{Hg}$ concentrations that were below the detection limit of the analytical instrument for the entire sampling period. Van Zyl et al. (2014) also indicated that $\mathrm{Hg}$ was below the detection limit of the analytical technique for aerosol samples collected at Marikana. This can be expected, since particulate $\mathrm{Hg}$ only forms a small fraction of the total atmospheric $\mathrm{Hg}$, with $\mathrm{Hg}$ being predominantly present in the atmosphere as gaseous elemental Hg (GEM) (Venter et al., 2015; Slemr et al., 2011).

\subsection{Seasonal variability}

The climate and weather of South Africa are characterised by its distinctive wet and dry seasons, which have an influence on concentrations of atmospheric species (Tyson and Preston-Whyte, 2000). Therefore, in Fig. 4, the total concentrations of the trace metal species in the $\mathrm{PM}_{1}$ (panel a), $\mathrm{PM}_{1-2.5}$ (panel b) and $\mathrm{PM}_{2.5-10}$ (panel c) size fractions measured at Welgegund for each month are presented, with the contributing concentrations of each of the trace metals indicated. In the $\mathrm{PM}_{1-2.5}$ and $\mathrm{PM}_{2.5-10}$ size fractions relatively higher total trace metal concentrations are observed from $\mathrm{Au}-$ gust to December. These periods coincided with the end of the dry season, which occurs in this part of South Africa typically from mid-May to mid-October (e.g. Tyson and PrestonWhyte, 2000). The end of the dry season is typically characterised by increases in wind speed in August (e.g. Tyson and Preston-Whyte, 2000). Therefore, these elevated trace metal concentrations determined in the $\mathrm{PM}_{1-2.5}$ and $\mathrm{PM}_{2.5-10}$ size fractions can partially be attributed to decreased wet removal in conjunction with increases in wind generation thereof. The $\mathrm{PM}_{1}$ size fractions also had relatively higher concentrations during the end of dry season period, especially during September and October. However, slightly higher trace metal concentrations are also observed in the $\mathrm{PM}_{1}$ size fraction in the austral winter months from June to August. This can be 
(a)

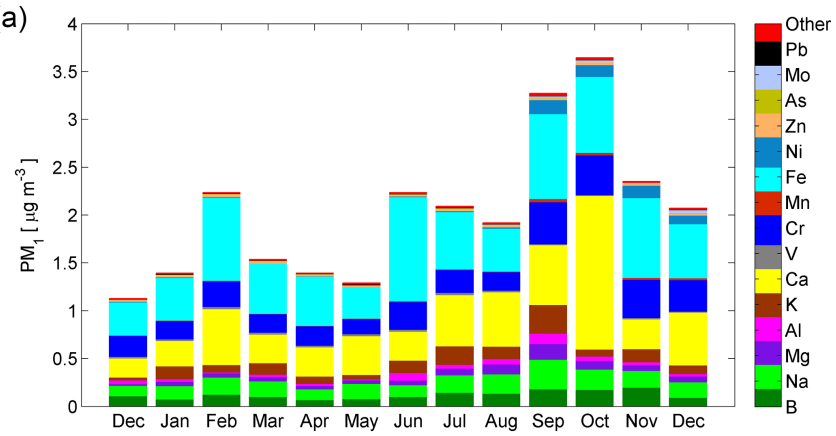

(b)

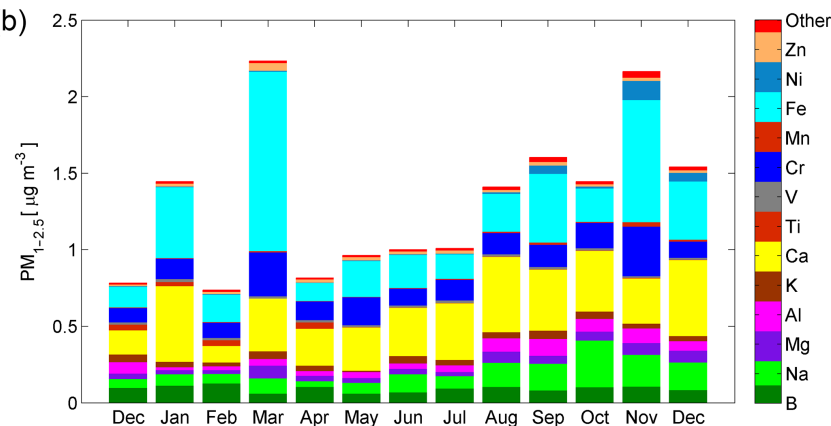

(c)

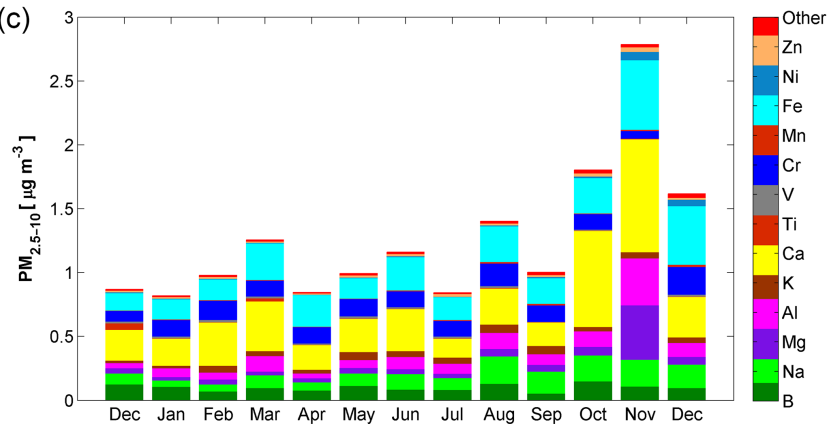

Figure 4. The monthly median trace metal concentrations in the $\mathrm{PM}_{1}$ (a), $\mathrm{PM}_{1-2.5}$ (b) and $\mathrm{PM}_{2.5-10}$ (c) size fractions.

ascribed to the presence of more pronounced inversion layers during this time of the year (e.g. Tyson and Preston-Whyte, 2000) that trap pollutants near the surface, which signifies the contribution of industrial sources to $\mathrm{PM}_{1}$ species.

The monthly concentrations of each of the trace metal species determined in the $\mathrm{PM}_{1}$ and $\mathrm{PM}_{1-2.5}$ size fractions reveal the highest contributions from $\mathrm{Fe}$ and $\mathrm{Ca}$ in both these size fractions for each of the months. The concentrations of $\mathrm{Na}$ and $\mathrm{Cr}$ that were the third- and fourth-most-abundant species, respectively, as well as the elevated levels of Al, B, $\mathrm{Mg}, \mathrm{Ni}$ and $\mathrm{K}$ are also reflected in the monthly distributions in the $\mathrm{PM}_{1}$ and $\mathrm{PM}_{1-2.5}$ size fractions. However, although $\mathrm{Fe}$ and $\mathrm{Ca}$ were slightly higher in the $\mathrm{PM}_{2.5-10}$ size fraction, a more even contribution from the concentrations of $\mathrm{Fe}, \mathrm{Ca}$, $\mathrm{Na}, \mathrm{Cr}, \mathrm{Al}, \mathrm{B}, \mathrm{Mg}, \mathrm{Ni}$ and $\mathrm{K}$ is observed (with the excep- (a)

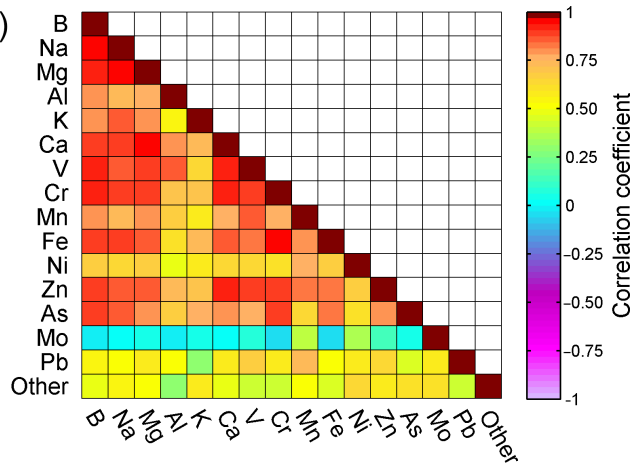

(b)

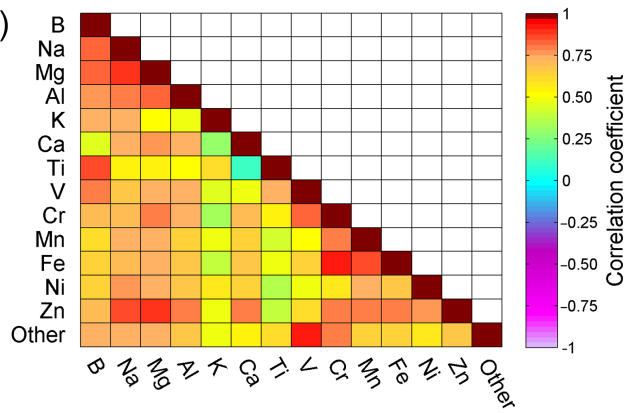

(c)

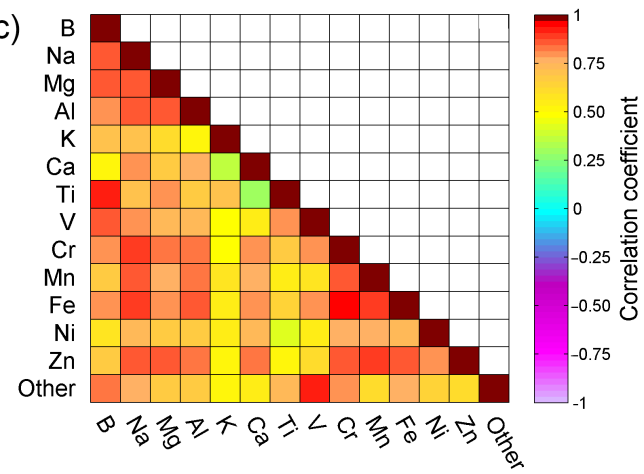

Figure 5. Spearman correlations of trace metal species in the $\mathrm{PM}_{1}$ (a), $\mathrm{PM}_{1-2.5}$ (b) and $\mathrm{PM}_{2.5-10}$ (c) size fractions.

tion of November as mentioned previously). This can be attributed to species in this larger size fraction consisting predominantly of wind-blown dust (Adgate et al., 2007) with no additional industrial sources of these species.

\subsection{Source apportionment}

As a first approach in the source apportionment investigation, Spearman correlation diagrams were prepared for each size fraction. In Fig. 5, Spearman correlations of the $\mathrm{PM}_{1}, \mathrm{PM}_{1-2.5}$ and $\mathrm{PM}_{2.5-10}$ size fractions are presented, i.e. Fig. 5a, b and c, respectively. From Fig. 5 relatively good correlations is observed between trace metals associated with pyrometallurgical activities, i.e. $\mathrm{Fe}, \mathrm{Cr}, \mathrm{Zn}, \mathrm{Mn}$ and $\mathrm{V}$ in all three size fractions. $\mathrm{Na}, \mathrm{Mg}$ and $\mathrm{Ca}$ also correlate with each other in all three size fractions, indicating the crustal (earth) influence. Relatively good correlations are also observed be- 

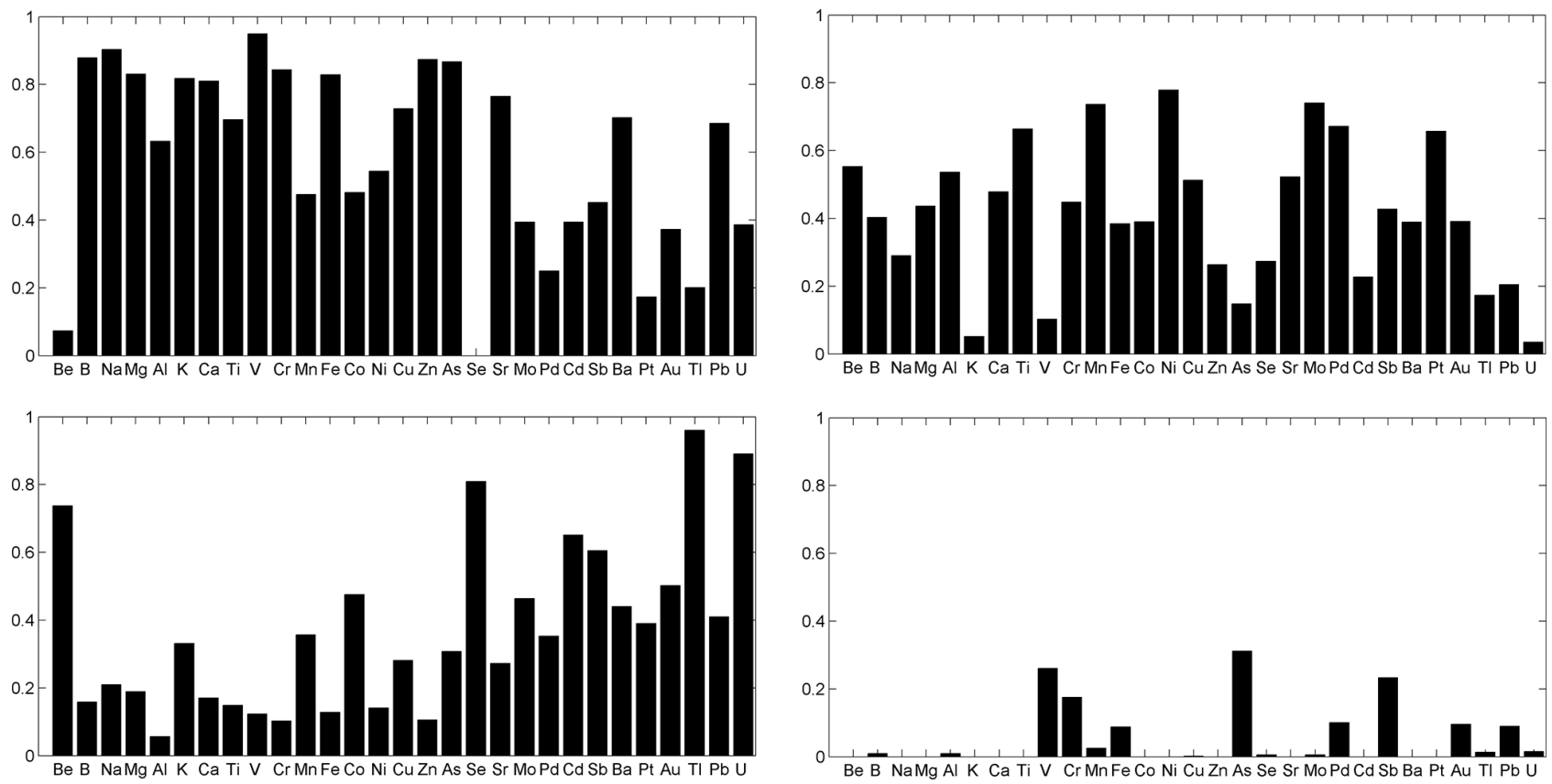

Figure 6. PCFA of the trace metal concentration in the $\mathrm{PM}_{1}$ size fraction. Four dominant factors are identified.

tween $\mathrm{Ti}$ and crustal species in the $\mathrm{PM}_{2.5-10}$ size fraction. In addition, these crustal species ( $\mathrm{Na}, \mathrm{Mg}$ and $\mathrm{Ca}$ ) also correlate with species associated with pyrometallurgical activities $(\mathrm{Fe}$, $\mathrm{Cr}, \mathrm{Zn}, \mathrm{Mn}$ and V). As mentioned in Sect. 3.1 and 3.2, although the influence of the pyrometallurgical smelters in the western Bushveld Complex is evident, the large influence of wind-blown dust on trace metal concentrations determined at Welgegund is also reflected, with approximately $30 \%$ of most of the trace metals being present in the $\mathrm{PM}_{2.5-10}$ size fraction.

In an effort to determine sources of trace metals, PCFA was applied as an exploratory tool, since much larger datasets are required for definitive source apportionment with PCFA. Therefore, only the most apparent groupings of metal species relating to expected sources in the region were identified. PCFA of the $\mathrm{PM}_{1-2.5}$ and $\mathrm{PM}_{2.5-10}$ size fractions did not reveal any meaningful factors. This was attributed to the large influence of wind-blown dust on trace metals measured at Welgegund, with all the factors obtained for the $\mathrm{PM}_{1-2.5}$ and $\mathrm{PM}_{2.5-10}$ size fractions containing mostly crustal species loadings. In Fig. 6, the factor loadings obtained for the $\mathrm{PM}_{1}$ size fraction are presented indicating four statistically significant factors with eigenvalues equal to or greater than 1 (Pollisar et al., 1998). These four factors obtained explained $88 \%$ of the variance.

Factor 1 explained $59.6 \%$ of the total system variance and was mainly loaded with trace metal species that are typically associated with wind-blown dust, i.e. $\mathrm{Ca}, \mathrm{Fe}, \mathrm{Na}, \mathrm{Mg}$ and Al (Adgate et al., 2007). Therefore, this factor was identified as the crustal factor. The contribution of small metal ore units from wind-blown dust is also reflected in this factor with a relatively high loadings of species such as $\mathrm{V}, \mathrm{Mn}, \mathrm{Zn}$ and $\mathrm{Cr}$. Mn is present in most of the ores from which metals are produced in the western Bushveld Igneous Complex. The smaller contribution from $\mathrm{Mn}$ than $\mathrm{Fe}$ in this factor is also indicative of wind-blown dust, since $\mathrm{Mn}$ is more volatile than Fe (Kemink, 2000). Therefore, a higher contribution is expected from $\mathrm{Mn}$ than $\mathrm{Fe}$ from pyrometallurgical sources.

Factors 2 and 3 explained 16.5 and $4.3 \%$ of the variance in the data and were identified as pyrometallurgical-related factors. Factor 2 revealed higher loadings of $\mathrm{Cr}, \mathrm{Fe} \mathrm{Mn}, \mathrm{Ni}$ and $\mathrm{Cu}$, while factor 3 was predominantly loaded with $\mathrm{Cr}$, $\mathrm{Fe}$ and $\mathrm{V} . \mathrm{Fe}$ and $\mathrm{Cr}$ are associated with the large number of ferrochromium smelters in the Bushveld Igneous Complex, while $\mathrm{Ni}$ is related to base metal smelters that refine base metals extracted from the PGM production processes. In addition, $\mathrm{Al}$ present in factor 2 is may be associated with fly ash formed during high-temperature processes, which include coal combustion. It must be noted that coal fly ash has a composition which is rather similar to that of crustal material (Mouli, et al., 2006). Mn has a substantially lower vapour pressure than most of the heavy metals produced in this region. Therefore, the coincidental influence of the pyrometallurgical industries is reflected by the high loadings of $\mathrm{Mn}$ and $\mathrm{Ni}$ in factor 2.

Factor 4 was considered to be indicative of trace metal species associated with slimes dams from Au mining and recovery in the region, which is especially signified by the $\mathrm{U}$ and Au loadings in this factor. In addition, this factor is mostly loaded with the metal species for which significantly 

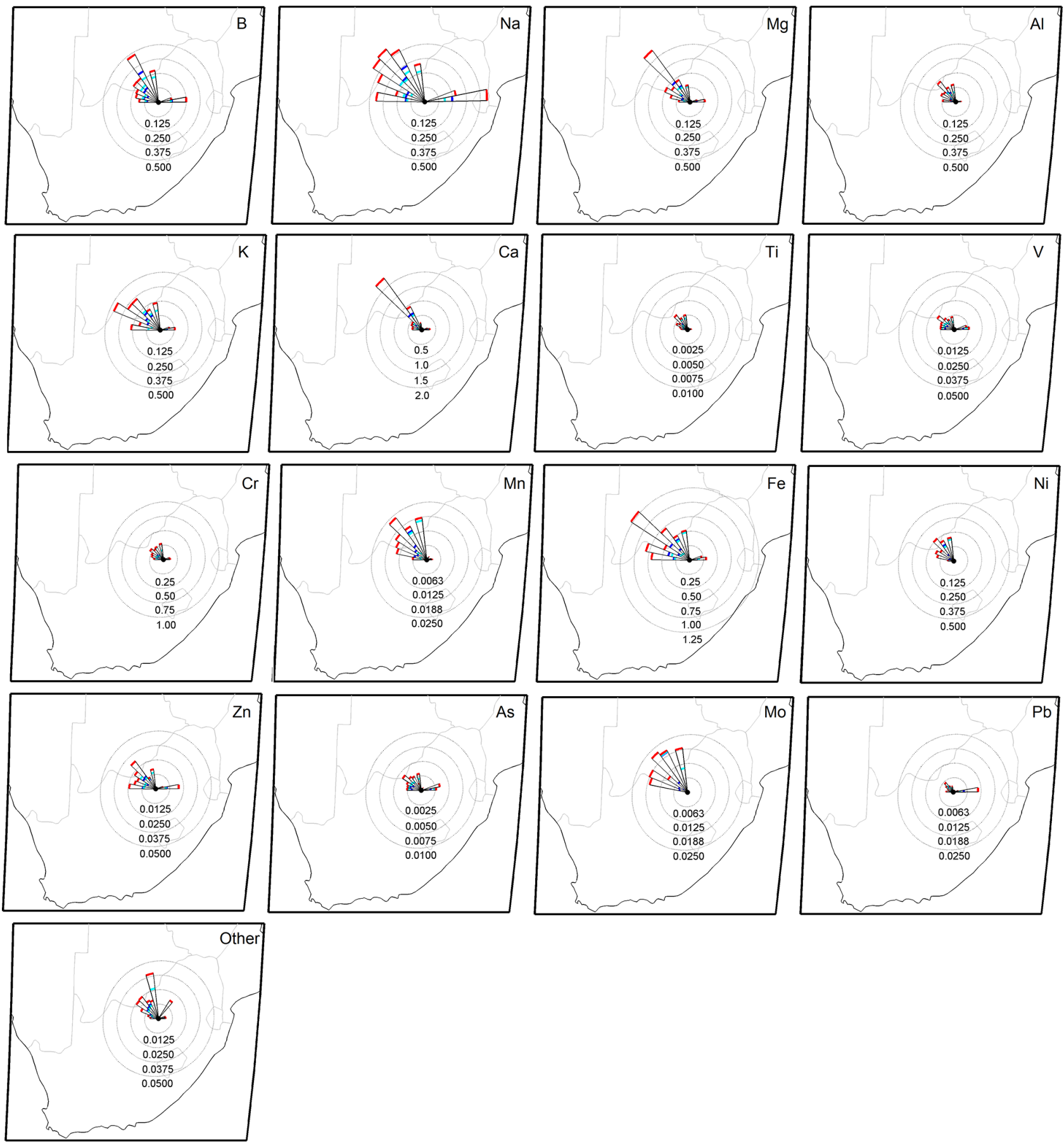

Figure 7. Pollution roses of trace metal species that were $25 \%$ or more of the time detected with the analytical technique.

lower concentrations were measured. This factor explained $7.6 \%$ of the total system variance.

Pollution roses of each of the trace metal species detected were also compiled in an effort to substantiate the sources identified with PCFA for the $\mathrm{PM}_{1}$ size fraction, as well as to verify the influence of wind-blown dust that contributed to obtaining no meaningful factors for $\mathrm{PM}_{1-2.5}$ and $\mathrm{PM}_{10-2.5}$. In Fig. 7, these pollution roses are presented, which indicate higher trace metal concentrations associated with wind directions from the north to western sector from Welgegund for all the trace metal species. As mentioned previously, the north to south-western sector from Welgegund is considered to be a relatively clean region without any large pollutant sources. Therefore, the most significant source of atmospheric trace metal species originating from this sector can be considered to be wind-blown dust (e.g. from the Karoo and Kalahari). 
This is also indicated by the higher atmospheric concentrations of specifically $\mathrm{Ca}, \mathrm{Fe}, \mathrm{Na}, \mathrm{Mg}, \mathrm{Al}$ and $\mathrm{Ti}$ associated with the north-western sector. Furthermore, the concentrations of trace metal species originating from the north can also be associated with pyrometallurgical industries in the western Bushveld Igneous Complex. The influence of these activities is reflected by the relatively higher concentrations of $\mathrm{Cr}, \mathrm{Ni}, \mathrm{Mn}, \mathrm{V}$ and As associated with winds originating in the north. It is also evident form these pollution roses that atmospheric Fe concentrations have contributions from windblown dust from the north-western sector, as well as from pyrometallurgical activities in the north.

\section{Conclusions}

Of the elements analysed in the aerosol samples, atmospheric Fe had the highest concentrations in all three size fractions, while $\mathrm{Ca}$ was the second-most-abundant species. $\mathrm{Cr}$ and $\mathrm{Na}$ concentrations were the third- and fourth-most-abundant species, respectively, while relatively higher concentrations were also determined for $\mathrm{Al}, \mathrm{B}, \mathrm{Mg}, \mathrm{Ni}$ and $\mathrm{K}$. With the exception of $\mathrm{Fe}$, which had higher concentrations in the $\mathrm{PM}_{1}$ size fraction, the concentrations of the trace metal species in all three size ranges were similar. With the exception of Ti, $\mathrm{Al}$ and $\mathrm{Mg}, 70 \%$ or more of the trace metal species detected were in the two smaller size fractions, which indicated the influence of industrial activities on trace metals measured at Welgegund. However, the large influence of wind-blown dust on trace metal concentrations determined at Welgegund is reflected by $30 \%$ or more of trace metals being present in the $\mathrm{PM}_{2.5-10}$ size fraction

A comparison of trace metal concentrations determined at Welgegund with trace metal measurements conducted in the western Bushveld Igneous Complex (Kgabi, 2006; van Zyl et al., 2014) indicated that $\mathrm{Fe}$ was also the most abundant species, while other trace metals determined at Welgegund were also measured in the western Bushveld Igneous Complex. However, concentrations of these trace metal species were significantly higher in the western Bushveld Igneous Complex. Trace metal concentrations were also compared to levels thereof in the Vaal Triangle (Kleynhans, 2008). $\mathrm{Fe}$ concentrations were similar to levels thereof at Welgegund, while concentrations of species associated with pyrometallurgical smelting were lower. Comparison to atmospheric trace metal species measured at international background sites indicated that trace metal concentrations at Welgegund were generally lower, with the exception of $\mathrm{Al}, \mathrm{Na}$ and $\mathrm{K}$ concentrations measured at Beijing, China (Duan et al., 2012), which were an order of magnitude higher. Annual average $\mathrm{Ni}\left(0.079 \mu \mathrm{g} \mathrm{m}^{-3}\right)$ were 4 times higher than the European Commission Air Quality Standards limit value, which could possibly be attributed to the influence of base metal refining in the western Bushveld Igneous Complex. As marginally exceeded the European Commission Air Quality
Standards limit value, which also reflects the regional impacts of pyrometallurgical industries.

All three size fractions indicated elevated trace metal concentrations coinciding with the end of the dry season. This could partially be attributed to decreased wet removal and increases in wind generation of particulates.

PCFA analysis revealed four statistically significant factors in the $\mathrm{PM}_{1}$ size fraction, i.e. crustal, pyrometallurgicalrelated and $\mathrm{Au}$ slimes dams. No meaningful factors were determined for the $\mathrm{PM}_{1-2.5}$ and $\mathrm{PM}_{2.5-10}$ size fractions, which were attributed to the large influence of wind-blown dust on atmospheric trace metals determined at Welgegund. Pollution roses confirmed this influence of wind-blown dust on trace metal concentrations, while the impact of industrial activities was also substantiated.

There are limitations associated with nitric digestion for ICP-MS analysis employed in this study, which could lead to the underestimation of aluminosilicates and metal species associated with it. X-ray fluorescence (XRF), for instance, is an alternative analytical method that can be used to assess the chemical composition of PM collected on filters. The use of this technique has many advantages, e.g. non-destructive technique, little sample preparation required, and relatively low cost per sample. In order to compare XRF with ICP-MS (digestion using ultrasonication in an $\mathrm{HF}-\mathrm{HNO}_{3}$ acid mixture) aerosol filter based analyses, Niu et al. (2010) analysed co-located duplicate samples collected in indoor and outdoor environments. Very good correlations for elements present at concentrations above the detection limits of both the ICPMS and energy dispersive-XRF methods were found. However, many more elements analysed by the ICP-MS technique passed the quality criteria proposed by the aforementioned authors, including elements typical for alumina silicates and other wind-blown dust compounds that were likely underestimated in the results presented in this paper. Therefore, although the digestion method used in this study is well established, it is recommended that future work should perform digestion using ultrasonication in an $\mathrm{HF}-\mathrm{HNO}_{3}$ acid mixture and, if possible, conduct both XRF and ICP-MS analyses since the results would supplement one another; e.g. elements below the detection limits of the XRF would be detected by the ICP-MS method.

Data availability. The data of this paper are available upon request to Pieter van Zyl (pieter.vanzyl@nwu.ac.za) or Paul Beukes (paul.beukes@nwu.ac.za).

\section{The Supplement related to this article is available online at doi:10.5194/acp-17-4251-2017-supplement.}

Competing interests. The authors declare that they have no conflict of interest. 
Disclaimer. Opinions expressed and conclusions arrived at are those of the author and are not necessarily to be attributed to the National Research Foundation (NRF).

Acknowledgements. The financial assistance of the NRF towards this research is hereby acknowledged. Ville Vakkari wishes to acknowledge financial support by the Academy of Finland Centre of Excellence programme (grant no. 272041).

Edited by: S. S. Gunthe

Reviewed by: three anonymous referees

\section{References}

Adgate, J. L., Mongin, S. J., Pratt, G. C., Zhang, J., Field, M. P., Ramachandran, G., and Sexton, K.: Relationships between personal, indoor, and outdoor exposures to trace elements in $\mathrm{PM}_{2.5}$, Sci. Total Environ., 386, 21-32, 2007.

Ahn, J. W., Chung, D. W., Lee, K. W., Ahn, J., and Sohn, H. Y.: Nitric Acid Leaching of Base Metals from Waste PDP Electrode Scrap and Recovery of Ruthenium Content from Leached Residues, Mater. Trans., 52, 1063-1069, 2011.

Beukes, J. P., Vakkari, V., Van Zyl, P. G., Venter, A. D., Josipovic, M., Jaars, K., Tiitta, P., Kulmala, M., Worsnop, D., Pienaar, J. J., Virkkula, A., and Laakso, L.: Source region plume characterisation of the interior of South Africa as observed at Welgegund, Clean Air Journal, 23, 7-10, 2013.

Booyens, W., Van Zyl, P. G., Beukes, J. P., Ruiz-Jimenez, J., Kopperi, M., Riekkola, M.-L., Josipovic, M., Venter, A. D., Jaars, K., Laakso, L., Vakkari, V., Kulmala, M., and Pienaar, J. J.: Sizeresolved characterisation of organic compounds in atmospheric aerosols collected at Welgegund, South Africa, J. Atmos. Chem., 72, 43-64, doi:10.1007/s10874-015-9304-6, 2015.

CDC, Centers for Disease Control: Agency for Toxic Substances and Disease Registry, available at: http://www.atsdr.cdc.gov/ toxprofiles/index.asp, last access: 14 July 2015.

Colbeck, I.: Environmental chemistry of aerosols, Oxford, UK, Blackwell Publishing Ltd, 2008.

Colbeck, I., Nasir, Z. A., Ahmad, S., and Ali, Z.: Exposure to $\mathrm{PM}_{10}$, $\mathrm{PM}_{2.5}, \mathrm{PM}_{1}$ and Carbon Monoxide on Roads in Lahore, Pakistan, Aerosol Air Qual. Res., 11, 689-695, 2011.

DEA, Department of Environmental Affairs: National Environmental Management: Air Quality Act, 2004 (ACT NO. 39 OF 2004) National ambient air quality standards, Government Gazette, Pretoria, South Africa, 24 December 2009, 6-9, 2009.

DEA, Department of Environmental Affairs: Notice 495 of 2012. Department of Home Affairs, National Environmental Management: Air Quality Act, 2004, Declaration of the Waterberg National Priority Area, South African Government Gazette No. 35345 on 15 June 2012; Correction notice (154): WaterbergBojanala National Priority Area, South African Government Gazette, Pretoria, South Africa, No. 36207 on 8 March 2013, 2012.

DEAT, Department of Environmental Affairs and Tourism: Declaration of the Vaal Triangle Airshed Priority Area in terms of section 18(1) of the National Environmental Management: Air Qual- ity Act 2004 (Act no. 39 of 2004), Government Gazette, Pretoria, South Africa, 21 April 2006, 2006.

DEAT, Department of Environmental Affairs and Tourism: Department of Environmental Affairs and Tourism. Declaration of the Highveld as priority area in terms of section 18(1) of the National Environmental Management: Air Quality Act 2004 (Act no. 39 of 2004), Government gazette, 23 November 2007, 2007.

Duan, J., Tan, J., Wang, S., Hao, J., and Chai, F.: Size distributions and sources of elements in particulate matter at curbside, urban and rural sites in Beijing, J. Environ. Sci., 24, 87-94, 2012.

ECAQ, European Commission on Air Quality: Air Quality Standards, Directive 2008/50/EC adopted on 21 May 2008, last updated: 19 November 2015, available at: http://ec.europa.eu/ environment/air/quality/standards.htm (last access: 1 December 2015), 2008.

IPCC: Climate Change 2014: Mitigation of climate change. Contribution of Working Group III to the Fifth Assessment Report of the Intergovernmental Panel on Climate Change, edited by: Edenhofer, O., Pichs-Madruga, R., Sokona, Y., Minx, J. C., Farahani, E., Kadner, S., Seyboth, K., Adler, A., Baum, I., Brunner, S., Eickemeier, P., Kriemann, B., Savolainen, J., Schlömer, S., Von Stechow, C., Zwickel, T., Working Group III Technical Support Unit, Cambridge University Press, New York, USA, 2014.

Jaars, K., Beukes, J. P., van Zyl, P. G., Venter, A. D., Josipovic, M., Pienaar, J. J., Vakkari, V., Aaltonen, H., Laakso, H., Kulmala, M., Tiitta, P., Guenther, A., Hellén, H., Laakso, L., and Hakola, H.: Ambient aromatic hydrocarbon measurements at Welgegund, South Africa, Atmos. Chem. Phys., 14, 7075-7089, doi:10.5194/acp-14-7075-2014, 2014.

Jaars, K., van Zyl, P. G., Beukes, J. P., Hellén, H., Vakkari, V., Josipovic, M., Venter, A. D., Räsänen, M., Knoetze, L., Cilliers, D. P., Siebert, S. J., Kulmala, M., Rinne, J., Guenther, A., Laakso, L., and Hakola, H.: Measurements of biogenic volatile organic compounds at a grazed savannah grassland agricultural landscape in South Africa, Atmos. Chem. Phys., 16, 15665-15688, doi:10.5194/acp-16-15665-2016, 2016.

Kemink, M.: A holistic environmental approach to the processing of off gas wastes arising from ferro manganese alloy production, Technicon Witwatersrand, Johannesburg, South Africa, 2000.

Kgabi, N. A.: Monitoring the levels of toxic metals of atmospheric particulate matter in the Rustenburg district, MSc Thesis, NorthWest University, Potchefstroom, South Africa, 2006.

Kleynhans, E. H.: Spatial and temporal distribution of trace elements in aerosols in the Vaal triangle, MSc thesis, North-West University, Potchefstroom, South Africa, 2008.

Mouli, P. C., Mohan, S. V., Balaram, V., Kumar, M. V., and Reddy, S. J.: A study on trace elemental composition of atmospheric aerosols at a semi-arid urban site using ICP-MS technique, Atmos. Environ., 40, 136-146, 2006.

Nel, A.: Air pollution-related illness: effects of particles, Science, 309, 1326, doi:10.1126/science.1108752, 2005.

Niu, J., Rasmussen, P. E., Wheeler, A., Williams, R., and Chénier, M.: Evaluation of airborne particulate matter and metals data in personal, indoor and outdoor environments using ED-XRF and ICP-MS and co-located duplicate samples, Atmos. Environ., 44, 235-245, doi:10.1016/j.atmosenv.2009.10.009, 2010.

Nriagu, J. O.: A global assessment of natural sources of atmospheric trace metals, Nature, 338, 47-49, 1989. 
Pacyna, J. M.: Source inventories for atmospheric trace metals, Atmospheric Particles, IUPAC Series on Analytical and Physical Chemistry of Environmental Systems, edited by: Harrison, R. M. and Van Grieken, R. E., Vol. 5, Wiley, Chichester, UK, 385-423, 1998.

Pacyna, J. M. and Pacyna, E. G.: An assessment of global and regional emissions of trace metals to the atmosphere from anthropogenic sources worldwide, Environ. Rev., 9, 269-298, 2001.

Pio, C. A., Castro, L. M., Cerqueira, M. A., Santos, I. M., Belchior, F., and Salgueiro, M. L.: Source assessment of particulate air pollutants measured at the southwest European coast, Atmos. Environ., 30, 3309-3320, 1996.

Polidori, A., Cheung, K. L., Arhami, M., Delfino, R. J., Schauer, J. J., and Sioutas, C.: Relationships between size-fractionated indoor and outdoor trace elements at four retirement communities in southern California, Atmos. Chem. Phys., 9, 4521-4536, doi:10.5194/acp-9-4521-2009, 2009.

Polissar, A. V., Hopke, P. K., Paatero, P., Malm, W. C., and Sisler, J. F.: Atmospheric aerosol over Alaska: 2. Elemental composition and sources, J. Geophys. Res., 103, 19045-19057, doi:10.1029/98JD01212, 1998.

Pöschl, U.: Atmospheric aerosols: Composition, transformation, climate and health effects, Angew. Chem. Int. Edit., 44, 75207540 doi:10.1002/anie.200501122, 2005.

Querol, X., Viana, M., Alastuey, A., Amato, F., Moreno, T., Castillo, S., Pey, J., De La Rosa, J., Sanchez De La Campa, A., Artinano, B., Salvador, P., Garcia Dos Santos, S., Fernandez-Patier, R., Moreno-Grau, S., Negral, L., Minguillona, M. C., Monfort, E., Gil, J. I., Inza, A., Ortega, L. A., Santamaria, J. M., and Zabalza, J.: Source origin of trace elements in PM from regional background, urban and industrial sites of Spain, Atmos. Environ., 41, 7219-7231, 2007.

Rubasinghege, G., Elzey, S., Baltrusaitis, J., Jayaweera, P. M., and Grassian, V. H.: Reactions on Atmospheric Dust Particles: Surface photochemistry and size-dependent nanoscale redox chemistry, J. Phys. Chem. Lett., 1, 1729-1737, doi:10.1021/jz100371d, 2010.

Seigneur, C. and Constantinou, E.: Chemical Kinetic Mechanism for Atmospheric Chromium, Environ. Sci. Technol., 29, 222231, doi:10.1021/es00001a029, 1995.

Slemr, F., Brunke, E.-G., Ebinghaus, R., and Kuss, J.: Worldwide trend of atmospheric mercury since 1995, Atmos. Chem. Phys., 11, 4779-4787, doi:10.5194/acp-11-4779-2011, 2011.

Tiitta, P., Vakkari, V., Croteau, P., Beukes, J. P., van Zyl, P. G., Josipovic, M., Venter, A. D., Jaars, K., Pienaar, J. J., Ng, N. L., Canagaratna, M. R., Jayne, J. T., Kerminen, V.-M., Kokkola, H., Kulmala, M., Laaksonen, A., Worsnop, D. R., and Laakso, L.: Chemical composition, main sources and temporal variability of $\mathrm{PM}_{1}$ aerosols in southern African grassland, Atmos. Chem. Phys., 14, 1909-1927, doi:10.5194/acp-14-1909-2014, 2014.
Tiwari, S., Chate, D. M., Srivastava, M. K., Safai, P. D., Srivastava, A. K., Bisht, D. S., and Padmanabhamurty, B.: Statistical evaluation of $\mathrm{PM}_{10}$ and distribution of $\mathrm{PM}_{1}, \mathrm{PM}_{25}$ and $\mathrm{PM}_{10}$ in ambient air due to extreme fireworks episodes (Deepawali fesivals) in megacity Delhi, Nat. Hazards, 61, 521-531, 2012.

Tyson, P. D. and Preston-Whyte, R. A.: The Weather and Climate of Southern Africa, Oxford University Press Southern Africa, Cape Town, South Africa, 2000.

Van Zyl, P. G., Beukes, J. P., Du Toit, G., Mabaso, D., Hendriks, J., Vakkari, V., Tiitta, P., Pienaar, J. J., Kulmala, M., and Laakso, L.: Assessment of atmospheric trace metals in the western Bushveld Igneous Complex, South Africa, S. Afr. J. Sci., 3/4, 11, doi:10.1590/sajs.2014/20130280, 2014.

Vakkari, V., Tiitta, P., Jaars, K., Croteau, P., Beukes, J. P., Josipovic, M., Kerminen, V.-M., Kulmala, M., Venter, A. D., Van Zyl, P. G., Worsnop, D. R., and Laakso, L.: Reevaluating the contribution of sulfuric acid and the origin of organic compounds in atmospheric nanoparticle growth, Geophys. Res. Lett., 42, 1048610493, doi:10.1002/2015GL066459, 2015.

Venter, A. D., Vakkari, V., Beukes, J. P., Van Zyl, P. G., Laakso, H., Mabaso, D., Tiitta, P., Josipovic, M., Kulmala, M., Pienaar, J. J., and Laakso, L.: An air quality assessment in the industrialised western Bushveld Igneous Complex, South Africa, S. Afr. J. Sci., 108, 1059, doi:10.4102/sajs.v108i9/10.1059, 2012.

Venter, A. D., Beukes, J. P., van Zyl, P. G., Brunke, E.-G., Labuschagne, C., Slemr, F., Ebinghaus, R., and Kock, H.: Statistical exploration of gaseous elemental mercury (GEM) measured at Cape Point from 2007 to 2011, Atmos. Chem. Phys., 15, 10271-10280, doi:10.5194/acp-15-10271-2015, 2015.

Venter, A. D., Beukes, J. P., Van Zyl, P. G., Josipovic, M., Jaars, K., and Vakkari, V.: Regional atmospheric $\mathrm{Cr}(\mathrm{VI})$ pollution from the Bushveld Complex, South Africa, Atmospheric Pollut. Res., 7, 762-767, doi:10.1016/j.apr.2016.03.009, 2016.

World Health Organization (WHO): Air quality guidelines - global update 2005, available at: http://www.who.int/phe/health_topics/ outdoorair/outdoorair_aqg/en/ (last access: 22 November 2015), 2005.

Zahn, H., Jiang, Y., Yuan, J., Hu, X., Nartey, O., and Wang, B.: Trace metal pollution in soil and wild plants from lead-zinc smelting areas in Huixian County, Northwest China, J. Geochem. Explor., 147, 182-188, 2014. 